\title{
Usefulness of Alternative' Integrative Assessment Methodologies in Public Decision Making
}

July 1978
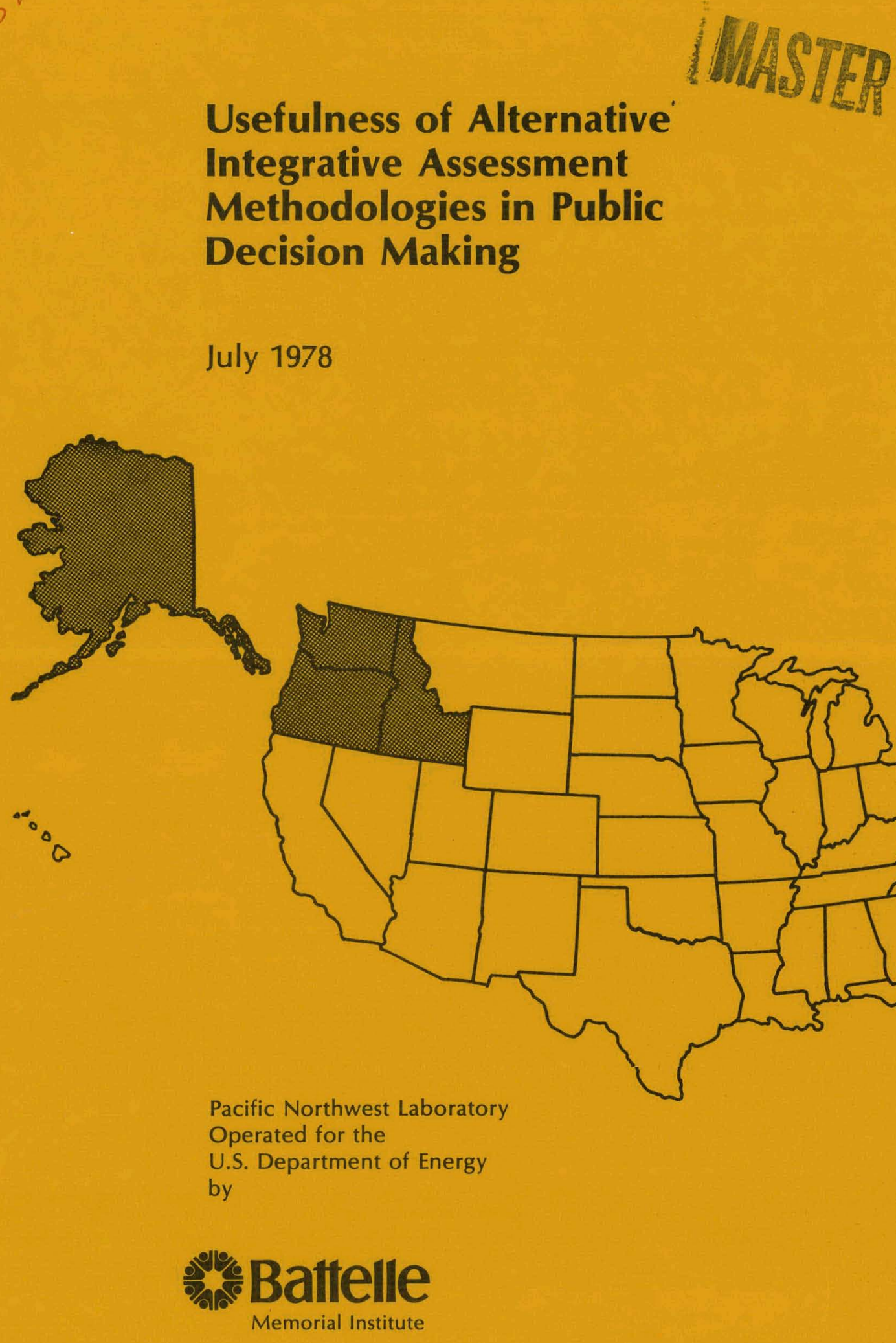


\section{DISCLAIMER}

This report was prepared as an account of work sponsored by an agency of the United States Government. Neither the United States Government nor any agency Thereof, nor any of their employees, makes any warranty, express or implied, or assumes any legal liability or responsibility for the accuracy, completeness, or usefulness of any information, apparatus, product, or process disclosed, or represents that its use would not infringe privately owned rights. Reference herein to any specific commercial product, process, or service by trade name, trademark, manufacturer, or otherwise does not necessarily constitute or imply its endorsement, recommendation, or favoring by the United States Government or any agency thereof. The views and opinions of authors expressed herein do not necessarily state or reflect those of the United States Government or any agency thereof. 


\section{DISCLAIMER}

Portions of this document may be illegible in electronic image products. Images are produced from the best available original document. 
NOTICE

This report was prepared as an account of work sponsored by the United States Government. Neither the United States nor the Department of Energy, nor any of their employees, nor any of their contractors, subcontractors, or their employees, makes any warranty, express or implied, or assumes any legal liability or responsibility for the accuracy, coinpleteness or usefulness of any information, apparatus, product or process disclosed, or represents that its use would not infringe privately owned rights.

The views, opinions and conclusions contained in this report are those of the contractor and do not necessarily represent those of the United States Government or the United States Department of Energy.

\author{
PACIFIC NORTHWEST LABORATORY \\ cperated by \\ B.ATTELLE \\ for the \\ UNITED STATES DEPARTMENT OF ENERGY \\ inder Contract EY-76-C-06-1830
}
Printed in the United Staies of America Available from
National Technical Information Service
United States Department of Commerce
5285 Port Royal Road
Springfield, Virginia 22151

Price: Printed Copy $\$$

*; Microfiche $\$ 3.00$

$\begin{array}{cc}\text {-Fages } & \begin{array}{c}\text { NTIS } \\ \text { Sellinig Ficice }\end{array} \\ 001025 & \$ 4.00 \\ 026-050 & \$ 4.50 \\ 051-075 & \$ 5.25 \\ 076-100 & \$ 6.00 \\ 101-125 & \$ 6.50 \\ 126-150 & \$ 7.25 \\ 151-175 & \$ 8.00 \\ 176-200 & \$ 9.03 \\ 201-225 & \$ 9.25 \\ 226-250 & \$ 9.50 \\ 257-275 & \$ 10.75 \\ 276-309 & \$ 11.00\end{array}$


USEFULNESS OF ALTERNATIVE INTEGRATIVE ASSESSMENT METHODOLOGIES IN PUBLIC DECISION MAKING

L. E. Erickson

J. W. Litchfield

J. W. Currie

C. L. McDonald

R. C. Adams

Ju7y 1978 sponsored by the United States Covernment. Neither the United States nor the United States Department of Energy, nor any of their employees, nor any of their contractors, subcontractors, of their employets, makes any warranty, express or implied, or assumes any tegas lisbility or responsibility for the accuracy, completeness or usefulness of any information, apparas pless process disclosed, or represents that its use would not infringe privately owned rights.

Prepared for the U.S. Department of Energy under Contract No. EY-76-C-06-i830

Pacific Northwest Laboratory Richland, Washington 99352 


\section{ACKNOWLEDGEMENTS}

Preparation of this paper was supported by funds from the U. S. Environmental Protection Agency which were passed through the U. S. Energy Research and Development Administration (now the U. S. Department of Energy) and the Los Alamos Scientific Laboratory (LASL): Additional funds were provided by the Office of Technology Impacts, Department of Energy.

Helpful comments provided by Andrew Ford and others at LASL on a draft of this paper are gratefully acknowledged. . 
This paper argues for more frequent use of formal integrative assessments in public decision making. One must always balance desirable and undesirable consequences of each alternative to arrive at a decision. An integrative assessment structures and documents this process.

Common aspects of integrative assessment methodologies are discussed and the steps necessary to the performance of integrative assessments are out 7 ined. In most respects, the two major integrative assessment methodologies, benefitcost analysis and multi-attribute utility analysis, are the same.

The key difference between these approaches is that in benefit-cost analysis all consequences are valued in dollars while in multi-attribute utility analysis they are valued in units called utils, which are specific to the analysis. Thus, the most important factor influencing the selection of benefit-cost or multi-attribute utility analysis to perform an integrative assessment is whether cne believes that all consequerces to be included in the analysis can be adequately valued in dollar terms.

Most of the paper focuses on the different approaches which benefitcost and multi-attribute utility analysis have taken to the estimation of the values of the consequences of decision alternatives in common units. Our intention in doing this is to provide the information necessary to decide whether benefit-cost or multi-attribute utility analysis should be selected in any particular instance. For each problem a single integrative assessment methodology must be selected. This is a choice which must be made by the decision maker for each public decision problem.

We find that multi-attribute utility analysis has traditionally relied more heavily on primary survey data than has benefit-cost analysis. While benefit-cost analysis has used prices from private markets as direct or indirect measures of value', reliance on primary data from bidding games is increasing. Thus the differences between the two integrative assessment methods are declining. We conclude that it is more important to use an integrative 
assessment methodology for important public decision problems than to worry too long about whether benefit-cost or multi-attribute utility analysis should be selected. 


\section{CONTENTS}

ACKNOWLEDGEMENTS ...............................

SUMMARY ............................... . . . . . . . . . . .

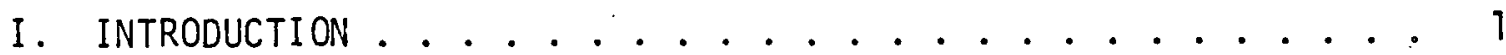

II. COMMON ASPECTS OF INTĖGRATIVE ASSESSMENT METHODOLOGIES . . . . 5

III. BENEFIT-COST ANALYSIS. . . . . . . . . . . . . . . 11

LIMITATIONS OF MARKET PRICES AS MEASURES OF VALUE . . . . 11

VALUING CONSEQUENCES IN DOLLARS . . . . . . . . . . 13

Private Market Proxies . . . . . . . . . . 13

Direct Inquiries . . . . . . . . . 16

INTEGRATING DOLLAR MEASURES OF VALUE. . . . . . . . 22

Selection of the Discount Rate....... . . 24

IV. MULTI-ATTRIBUTE UTILITY ANALYSIS . . . . . . . . 30

ALTERNATIVE UTIL SCALES ............ . . 31

VALUING CONSEQUENCES IN UTILS ........... 31

Paired Comparisons . . . . . . . . . 32

Direct Scaling . . . . . . . . . . . 33

Lottery Methods. . . . . . . . . . . . 33

INTEGRATING UTIL MEASURES OF VALUE. . . . . . . . . 35

Intertemporal Comparisons. . . . . . . . 35

v. COMPARISON OF INTEGRATIVE ASSESSMENT METHODCLOGIES . . . . 38

VALUE ESTIMATION. . . . . . . . . . . . . . . . . . 38

UNCERTAINTY . . . . . . . . . . . . . . . . . 39

INTERTEMPORNL COMPARISONS ........... 40

ASSUMPTIONS ........................ 41

REFERENCES ............... 43 


\section{USEFULNESS OF ALTERNATIVE INTEGRATIVE ASSESSMENT \\ METHODOLOGIES IN PUBLIC DECISION MAKING}

\section{INTRODUCTION}

Many diverse social, economic and environmental effects are associated with each of the available energy development alternatives. The assessment of the costs, risks and benefits of these energy development options is an important function of the U.S. Department of Energy. This task is more difficult when no single alternative is better than the others in all respects. This paper compares benefit-cost and multi-attribute utility analysis as decision aids for these more difficult and more common assessment cases:

PNL has developed expertise in making these assessments through its involvement since the Calvert Cliffs decision in both the preparation of Environmental Impact Statements and the development of methods to make these statements more thorough and responsive to the spirit of the National Environmental Protection Act (NEPA). Since 1973 PNL has had continuing efforts to quantify, value and compare all of the major factors which influence the overal1 impacts of energy development options. An important part of this work has been the measurement and incorportation of the relative values which community groups place on these conflicting factors.

Such difficult assessment problems could be approached in many ways including the use of benefit-cost or multi-attribute utility analysis. This paper addresses the following questions: (1) Should an integrative assessment methodology ce used for the overall assessment of these costs, risks, and benefits? (2) If an integrative assessment methodology is to be used, what alternative method's are available and what should be the basis for selecting a method? (3) Is it possible to use one of the available alternatives for. one portion of the assessment and another for another portion of the assessment? The answers to these questions presented in this report are applicable to most public decision problems.

In this section we consider what an integrative assessment is and the advantages of conducting such an assessment. Every decision we make involves the selection of one of a number of competing alternatives. By an assessment we mean the process of comparing and evaluating these alternatives so that 
one of them can be selected. Frequently one of the alternatives is superior to the others in some way(s) and another alternative is superior in another way $(s)$. In such cases it is necessary to weigh the importance of performing well in these different respects. The formal process of doing this we call integration or aggregation of these impacts into common units. Thus, a fully integrated assessment values all of the impacts of each alternative decision in common units so that they can be more readily compared to identify the preferred alternative.

In siting electric power plants, for example, it is not possible to select a site which has no undesirable consequences. Rather, the balancing of the desirable and undesirable consequences associated with each alternative is a necessary part of such decisions. An integrative assessment formalizes and structures this process.

While most public decision making bodies recognize the need for some kind of justification of their decisions, most of these agencies do not develop a complete list of viable alternatives and do not perform any kind of integrative assessment of the desirability of following any given alternative. Many public decisions are not well documented; it is not easy to find out just how these decisions were made. Most of the time the test that can be hoped is that someone will be able to remember what factors were considered and what were not; but usually even this is not clear. The boundary between included and excluded factors is frequently not well defined. The decision making procedures do not follow a clear structure and are not easily replicable by others. The value judgments which were used are not usually identified.

Nevertheless, everyone does not agree that formal integrative assessments can be an aid to decision makers. Researchers at the University of Oklahoma (1976), for example, believe that it is not only useless to the decision maker but actually misleads him. While these people do agree that it is useful to identify all of the significant consequences that can be expected to result from the selection of any one of the alternatives, they balk at integrating all of the desirable and undesirable consequences of each alternative into common units. 
There are several advantages to using an integrative assessment methodology as an aid in public decision making:

(1) following such a procedure helps to document the decision process:

(2) consequences which are included must be clearly defined and, at least by omission from this list, those consequences not included are also specified;

(3) an integrative assessment methodology also provides a structure to document the process by which the decision is reached. This helps to focus later discussions on (a) the methodology, (b) the data, (c) the consequences and/or (d) the value judgments used in reaching the decision; and

(4) because the methodology, data, consequences, and value judgments used in assessing the relative merits of the various alternatives are clearly specified, this procedure is more easily replicable by others and easier to expiain. Everyone still may not agree with the decision, but at least the sources of the disagreement can be identified.

Some factors may be very difficult to quantify and value. These factors are generaliy omitted from many analyses, but an integrative assessment methodology encourages the inclusion of all relevant factors in the final decision even if some of these must be omitted from the analysis due to measurement difficulties. When an integrated assessment is presented to the decision maker, he may find that the alternative which appears to be best based on this analysis is not the one that he had intuitively felt ought to be chosen. If this is the case, he will be encouraged by this divergence to discover. what factors may have been omitted from the analysis which lead him to feel the way he does. Especially in such cases, an integrative assessment can provide additional information to the decision maker which can be very valuable to any decision maker, even if he decides that because some factors have been omitted from the analysis, the alternative recommended by the analysis should not, in fact, be selected.

If it were possible to perform a fully integrated assessment which the decision maker could not fault for omitting some important consequence of somc alternative from the analysis or for methodological or procedural 
errors, then the integrative assessment could be more than-an aid to the decision maker; there would be no reason for the decision maker not to follow the advice recommended by the integrative assessment. However, to the extent that such inadequacies do exist, integrative assessments are an aid to the person making the decision and should not be viewed as a substitute for him.

There are two major integrative assessment techniques available: benefit-cost analysis and multi-attribute utility analysis. The conceptual similarities of these approaches are discussed in the next section as they relate to public decision problems. Sections III and IV discuss benefit-cost analysis and multi-attribute utility analysis, respective$1 y$, as they have been applied to public decision problems. These sections emphasize the different approaches which have been taken to integration of the desirable and undesirable consequences of alternatives into common units. The final section compares benefit-cost and multi-attribute utility methods for integrative assessment and suggests criteria for selection of one of these methodologies for any particular public decision problem. 


\section{COMMON ASPECTS OF INTEGRATIVE ASSESSMENT METHODOLOGIES}

In this section we discuss the common elements of all integrative assessment methodologies as applied to public decision problems. In most respects benefit-cost analysis and multi-attribute utility analys is approach integrative assessment in the same way. We also identify those elements of the integrative assessment process which are approached differentiy in the two al ternative methodologies.

In this discussion of the common aspects of integrative assessment methodologies we will lead the reader through Figure 1. Every decision must begin with the definition of an overall goal: For most public decisions this goal is to select that alternative which will lead to the greatest possible increase in social welfare. When the results of a public decision are that some people gain and no one loses, then we can be sure that social welfare is increased by such a decision. Further, any result where some people gain and others lose. could be transformed into a clear increase in social welfare if those who gain were able to use these gains to compensate those who lose for their losses.

Given this goal the persons whose values are relevant to the analys is are those who can be said to represent the views of society on the decision at hand. To identify these persons one must note whether the boundary of the analysis is defined to include as "important" consequences things which impact a given person or group of persons. For example, in deciding whether to have dispersed or clustered siting of power plants in the westeern U.S., one may decide that boom town effects, such as temporary shortages of social services, are important consequences of the siting decision. If this is the case, then persons who would be directly impacted by these boom town effects would be the persons whose values would most likely represent the overall impacts on society of the boom town effects.

Before one can determine whether the boundary of the analys is does include a particular consequence, one must select objectives which contribute 


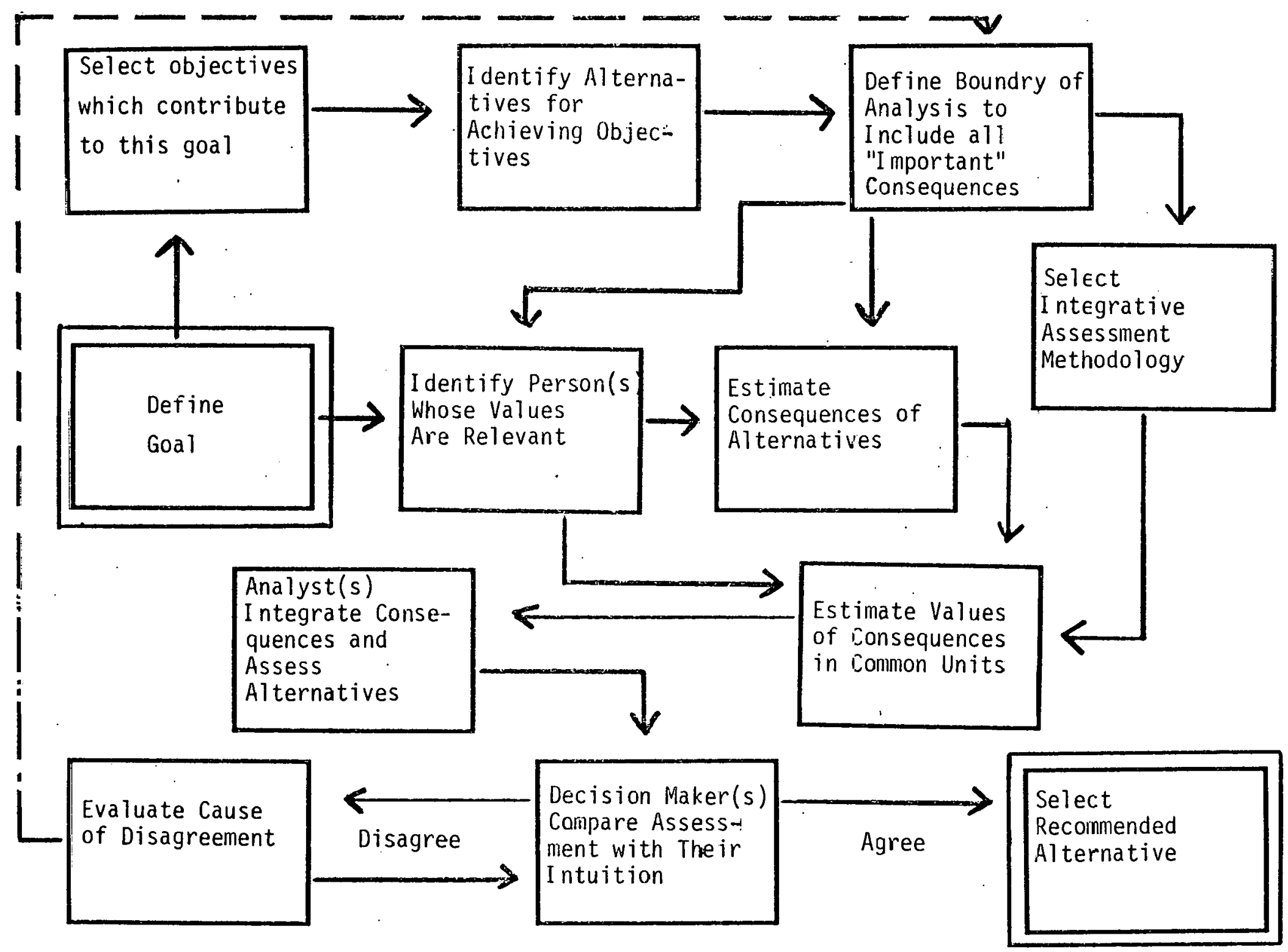

FIGURE 1. Elements of an Integrative Assessment 
to the overall goal and identify the available alternatives for achieving these objectives. Objectives relevant to a power plant siting decision, the goal of which is the greatest increase in social welfare, might iriclude:

(1) a low price of electricity to the consumers of electricity, (2) maintainirg the distant vistas common in the western U.S., and (3) having little disruption of the lives of individuals located in the site area. The alternatives would be alternative sites and generation types available. This would include clustering plants in a single location or dispersing them over a wider area.

Having selected the objectives and identified the alternatives, one can determine whether the selection of one of the alternatives is likely to have consequences which significantly impact the objectives which were selected. To the extent that consequences are deemed important to the analys is the boundary of the analysis should be defined to include them.

Having determined which consequences are important the next step is to estimate in physical terms what the consequences of each of the al ternatives would be. In doing this one should select physical units which are likely to be meaningful to the persons whose values are relevant to the decision.

At this point one must decide whether benefit-cost or multi-attribute utility analysis will be used to perform the integrative assessment. The most important factor influencing one's selection of benefit cost.or multiattribute utility analysis to perform the integrative assessment is whether the boundary of the analysis has been defined to include "important" consequences which one believes cannot be accurately valued in dollar terms. This is because benefit-cost analysis values all consequences in dollar terms, while multi-attribute utility analysis values them in arbitrary util terms. In Sections III and IV of this report we will concentrate on the different approaches which benefit-cost and multi-attribute utility analysis take in estimating and integrating the values of consequences in common units. 
In estimating these values, there are several common problems which must be addressed. These issues, which will be addressed in more detail in Sections III and IV, include:

(1) The value of some consequence may depend on the extent of other consequences and on the existing environment of the persons whose values are being estimated;

(2) in estimating the consequences and in estimating the value of these consequences, much undertainty may exist and people may be averse to such risks;

(3) values may change between the time of their measurement and the time of implementation of the decision;

(4) the quality of both secondary and primary survey data may be questionable for a variety of reasons;

(5) when different alternatives have different impacts on different groups in society, it is important but also difficult to measure the value of these equity considerations to the group whose values are considered relevant; this difficulty is more broadly seen in the problem of developing group utility functions or social welfare functions;

(6) effects occur in different time periods and these temporally dispersed impacts must be integrated.

Once the relative values of the consequences have been estimated, the analyst can integrate the values of these consequences and assess the alternatives. The value of each alternative is found by summing the values of all of the consequences of this alternative. The value of each consequence of each alternative is in turn equal to the relative value times the extent of this consequence. The alternative with the highest total value of all con sequences would then be recommended to the decision maker.

In order to validly determine the value of an alternative by summing the value of all of the consequences of this alternative, one must assume that the value of each consequence is, for the purposes of the analysis, unaffected 
by the extent of the other consequences. Benefit-cost analysis and multiattribute utility analysis make different assumptions to accomplish this, but any integrative assessment methodology must address this issue. An important: companion assumption is that the relative value of the consequences are not dependent on the extent of the consequences.

Thus far we have implicitly assumed that all of the consequences of all of the alternatives and their relative vaiues can be known with certainty. In general decisions must be made in spite of much uncertainty regarding the extent of the consequences and their relative values. The most common approach to incorporating this undertainty into the analysis is to use the expected value of the consequences.

If the analysis which has been performed does not violate the decision maker(s)'s intuition, then he will select the recornmended alternative. If the decision maker(s) disagrees with some portion of the analysis or does not understand why the alternative which has been recommended should be selected, this disagreement must be resolved before an alternative can be selected. This may require that the boundary of the analysis be redefined to include soms consequence which had been overlooked but. which the decision maker feels is important enough to be included. This emphasizes the importance of having the decision maker interact with the analyst at various stages in the integrative assessment process. Such interactions should at least occur in the definition of the overall goal and in the definition of the boundary of the analysis.

Following the integrative assessment procedure outlined in this section would identify the roles of each of the significant individuals involved. These individuals include: (1) the researchers estimating the consequences of each of the alternatives. (2) the researchers estimating the value of these consequences, (3) the persons whose values are estimated and included in the analysis, and (4) the decision maker. Each of these individuals or groups has distinct and important functions. 
In this section we have seen that the key factor influencing the choice between benefit-cosi and multi-attribute utility analysis is whether one believes that all of the important consequences of each alternative can be accurately valued in dollar terms. In the next section we review the approaches used in benefit-cost analysis to value consequences in dollar terms. 


\section{II . BENEFIT-COST ANALYSIS}

This section discusses the most commonly used (and misused) integrative assessment methodology: benefit-cost analysis. The primary feature distinquishing benefit-cost analysis from multi-attribute utility analys is is the use of dollar units for the valuation of the consequences of the alternatives. Those consequences which have positive dollar values are included in the benefits and those consequences which have negative dollar values to the individuals whose yalues are relevant to the problem at hand are included in the costs.

Some benefits and costs may be directly valued using private market prices. In the next part of this section we discuss the conditions which may limit the ability to use market prices as an accurate reflection of value. Benefit-cost analysis has been frequently misused due to the omission from the analysis of benefits and costs which cannot be accurately valued by using private market prices directly. The second major part of this section reviews the available approaches to valuing benefits and costs in dollar terms when private market prices cannot be used directly as an accurate reflection of value. . The last part of this section discusses the approaches used in comparing benefits and costs once they have been valued in dollar units. This final part includes a discussion of approaches to intertemporal comparisons which could be equaliy applicable to multiattribute utility analysis but which have not generally been applied outside benefit-cost analysis.

LIMITATT ONS OF MARKET PRTCES AS MFASUIRES OF VALUIE

In the welfare economics literature it has been shown that under certain conditions the interaction of numerous individuals, all of whom act in the best interests of themselves as individuals, will lead to the most efficient possible allocation of society's resources. When thcse conditions do not hold, the equilibrium private market prices of some commodities do not reflect the value of these items to society and "market failures" are said to exist. If there were no market failures, the equilibrium private market prices of all commodities would reflect the value of these items to society at the 
margin. Thus, if there were no market failures, benefit-cost analyses could be performed using market prices excloively to measure the benefits and costs at the margin.

However, market failures do frequently exist, forcing the analyst to employ other techniques for measuring the benefits and costs in such cases. These market failures can be divided into two major categories: (1) Imperfectly.competitive markets, and (2) Externalities (Erickson (1977)).

Imperfectly competitive markets are one of the two major types of market failure. When markets are not perfectly competitive, suppliers can restrict output and raise prices compared to the perfertily rompetitive equilibrium output and price. Because some people will then be willing to pay more for an additional unit of output than it costs to produce, production should increase to be socially optimal; but there are no private incentives to do this.

In the absence of government sanctioned cartels or monopolies, imperfectly competitive markets are caused by economies of scale in the production process. Because the extent of economies of scale is defined with respect to the size of the market, there are two major reasons why significant economies of scale may exist: (1) There may be significant indivisibilities in the factor inputs to the production process. (2) Market.s may be spatial1y. limited either because of significant transportation costs for certain commodities, such as concrete, compared to their value or because of political boundaries (Greenhut and Ohta (1975)).

Externalities are the other major type of market failure. When externalities exist all the benefits of consumption and/or all the costs of production are not reflected in the private market demand and supply curves, respectively, and the normal operation of unregulated perfectly competitive private markets will cause over- or under-production and consumption of some goods. All types of externalities may be either positive or negative. If a positive externality exists, too little of the associated good will be produced and consumed; if a negative externality exists, too much of the associated good will be produced and consumed compared to the sccially optimal quantity. 


\section{VALUING CONSEQUENCES IN DOLLARS}

There are two major approaches to the doliar valuation of benefits and costs which can be used when direct use of private market prices is inappropriate due to market failures: (1) observed behavior may be used to infer the value of these benefits and costs to people, and (2) direct inquiries as to the behavioral intentions of people can be used to obtain values for these benefits and costs. The approach selected in an individual case depends on the nature of the information which is available and the funds available for the analysis.

\section{Private Market Proxies}

Changes in the amount of an externality often induce changes in individual behavior which are reflected indirectly in private markets. For example, the value of human health effects of air pollution can be measured by medical expenses incurred, and wages and productivity lost. Health effects have a "pain and suffering" component which is not valued in this way, al though litigation results may provide some idea of their magnitude. However, quick and quantitative results are usually more easily obtainable with private market proxies than with direct inquiry methods of valuing externalities. There are three basic ways which have evolved to generate private market proxies which can be used as social value estimates of extra-market production and consumption: a] ternative cost, willingness to accept compensation and willingness to pay (D'Arge (1975)).

\section{Alternative Cost Approach}

The alternative cost approach estimates the difference between what the consumer pays in private markets to maintain his current state with the externality and what he would have to pay to maintain his current state without the externality. This approach uses the minimum cost of providing a service or substitute for a service without considering the effects as a measure of the value of this service. As such, it is always less than or equal to the theoretically correct value of the service.

For example, an impact of air pollution on a house may be increased deterioration of exterior paint. Increasing the rate at which the house is painted is one way of returning a house to its original state. If the 
least cost way of returning a house to its original state is by painting it, then this is a measure of the alternative cost of air pollution. If there are no other ways of compensating the owner for the damage, then the alternative cost measure is a reasonable approximation of the extra-market costs of air pollution on the house.

\section{Willingness to Accept Compensation Approach}

The willingness to accept compensation approach yields a more theoretically correct measure of value than the alternative cost approach. It is the minimum compensation an individual would accept to (1) be subjected to a higher level of a negative externality assuming he has the right to avoid it, or (2) forego a higher level of a positive externality assuming he has the right to get it.

For example, the minimum amount the home owner would accept to allow continued air pollution might be the cost of replacing the painted siding on his house with corrosive resistant siding. If the only extra-market effects from air pollution were paint damage, and if the home owner has the right to avoid the pollution, then this would be a reasonable estimate of the extra-market costs of air pollution.

\section{Willingness to Pay Approach}

This approach also yields theoretically correct measures of value; in this sense it is similar to the opportunity cost approach. It is the maximum amount an individual would be willing to pay to (1) avoid being subjected to a higher level of a negative externality assuming he does not have the right to avoid it, or (2) get a higher level of a positive externality assuming he does not have a right to get it.

In our example, this would be the maximum amount the home owner would be willing to pay to avoid having the paint on his house damaged. In general, this will be less than the minimum amount he would have to be compensated to allow the pollution because of the difference in the assumption about his rights. 
One method of estimating willingness to pay to avoid pollution uses data from the real estate market. This property value approach to measuring the change in social value due to the introduction of an externality assumes that the real estate market has the potential to reflect the aggregation of the majority of the effects of an externality. Consider two areas which are identical except for environmental quality. If all potential buyers of land in these two areas had identical preferences, the price differential between these. two areas in equilibrium would equal an individual's willingness to pay for the difference in the level of environmental quality. In general, land values between areas differ for many reasons and the extent of the differences attributable to air pollution and other factors must be estimated econometrically.

The assumptions required for changes in land values to. measure the change in social value due to the differential levels of the externality are extremely restrictive and generally unrealistic (Maler (1977)). However, there is a lack of empirical work to determine the extent to which the unrealistic assumptions cause a deviation in the land value changes from the change in social value. This type of empirical work is needed in order to make a meaningful conclusion concerning the usefulness of the property value approach.

Freeman (1974) has devised an alternative procedure for estimating the social value of an externality using property value data. His approach is based upon the use of household income compensated demand curves, which are a function of air quality. This function represents the marginal willingness to pay or marginal benefit function for the household for changes in the level of air quality. Thus, the aggregate benefit for a change in the level of air quality would equal the area under this curve between these air quality levels summed over all households. That is,

$$
B=\sum_{j=1}^{n} s_{Q_{i}}^{Q_{j}^{\prime}} D_{i}\left(Q_{j}\right) d Q_{i} .
$$

Although. Freeman's procedure is theoretically correct, its implementation would be expensive. 


\section{Direct Inquiries}

The second major approach to valuing externalities is to measure their perceived value to people using bidding games and other forms of direct inquiries. While private market proxies infer value from observed behavior, direct inquiries rely on an individual's statement of his past behavior or behaviorial intentions.

There are two major direct inquiry approaches: the utility-demand approach and the direct bid approach. Both approaches involve a gaming situation, usually from a personal interview, and both involve a form of role playing on the part of the respondent. While they are usually used to develop measures of intended behavior, in some cases the responses are based on historical partial purchases of the commodity in question.

\section{Utility-Demand Approach}

The utility demand approach operationalizes all of the steps of the neoclassical economic theory of consumer behavior. This approach is most often used to assess the value of new products and in other instances when perfectly competitive private markets could exist but do not.

This approach begins with the measurement of an individual's utility or value function which quantitatively represents his subjective feelings about various possible consequences. The classical way of incorporating the individual's feelings about the uncertainty of these consequences is credited to von Neumann and Morgenstern (VNM) (1947). Baquet (1974) summarizes the four methods for measuring an individual's utility or value function: direct measurement, (2) the VNM method, (3) the modified VNM method, and (4) the Ramsey method. 
All of these utility-demand approaches use responses to a series of questions to measure utility functions. The simplest direct method assumes that the marginal utility of money is the same at all income levels. This assumption of constant marginal utility of money may not be realistic for many persons. To relax this assumption, other approaches have been introduced.

The vNM method assumes that if $x_{1}$ is preferred to $x_{2}$, and $x_{2}$ is preferred to $x_{3}$, then there exists some probability $\dot{P}$, such that

$$
P \cdot U\left(x_{1}\right)+(1-P) \cdot U\left(x_{3}\right)=U\left(x_{2}\right) \text {. }
$$

That is, the certain prospect of $x_{2}$ has the same value as the uncertain prospect of $x_{1}$ or $x_{3}$. For $x_{1}, x_{2}$, and $x_{3}$, direct questioning is used to determine the value of $P$ for which this equality holds. By choosing an array of values for $x_{2}$ between $x_{1}$ and $x_{3}$ and then finding the corresponding value of $P$, the utility curve between $x_{1}$ and $x_{3}$ can be plotted.

The VNM method measures an individual's like or dislike of gambling and his preference for or against certain probabilities as well as the value of the commodity in question. The modified VNAl method uses neutral probabilities of $P=0.5=1-P$ so that the respondent is always faced with a 50-50 gamble between $x_{1}$ and $x_{3}$. While this method does not measure the individual's preference for certain probabilities, it still includes in the utility or value function the individual's preference for or aversion to gambling. (These VNM methods of utility measurement have also been used in multi-attribute utility analysis. See page 34 below)

The Ramsey (1964) method offers a choice between two uncertain prospects and uses neutral probabilities. In this method, the utility function is derived by playing a series of games to determine the utility levels associated with various monetary outcomes. Because the utility functions are expected to be nonlinear, at least three points on each function are necessary. Research to date suggests that the modified vNM and Ramsey methods are superior to the VNM method (Baquet (1974)). The Ramsey method, while giving the most consistent results, requires more complicated questioning and is, thus, more expensive to use. 
Once the utility functions are measured, the utility-demand approach derives consumer demand functions from the analysis of utility maximization given income and relative prices. The individual demand curves may then be aggregated to obtain a market demand curve. While this has been a standard procedure for the analysis of new private market products, it has also been used in estimating the value of recreation experiences.

Recreation benefits or losses resulting from public projects have traditionally been measured by looking at how much people pay for the opportunity to enjoy a similar recreation experience in a similar area. This procedure always uses the cost of travel to the site but should also include depreciation on equipment which is specialized to the type of recreation in question, and the value of the time spent recreating and enroute. These data are then used to estimate an aggregate demand curve from which a "consumers' surplus" measure of benefits is derived. This consumers' surplus is the amount people are willing to pay in excess of what they do pay for a product.

Mäler (1977) has critized the use of aggregate demand curves to value public or private goods. He emphasizes the problems involved with the use of aggregate demand curves to calculate consumers" surplus and willingness to pay. The only conditions under which such values can be reliably determined is if (1) the income distribution is fixed in such a way that each individual is receiving a determined fraction of the total income, (2) ail individuals are identical, and (3) they all have homothetic utility functions.

Sinden (1973, 1974) criticized the travel cost approach to.valuing recreation experiences because of its reliance on the constancy of tastes assumption across all consumers. He argued that modification of this approach to allow for variable tastes is intuitively appealing. Because the basic measure of value is the utility obtained from time and money budgets, sinden argued that values can and shouid be measured by directly estimating individual utilities rather than by indirect estimates of aggregate consumers' surplus from demand functions. 
Sinden compared the travel cost and Ramsey methods in an empirical study of recreational and aesthetic experiences. He found that the costs of applying both methods were essentially equal for a given level of accuracy, but the Ramsey method was significantly more powerful in predicting recreation consumption. Also, the benefit estimates obtained with the Ramsey method of estimating indifference curves were nearly twice those estimated by the traditional travel cost approach. This is consistent with economic theory which suggests the travel-cost approach, being an indirect measure of utility, will lead to under-estimation of the benefits. A final advantage of the Ramsey indifference curve approach is that the benefit measure obtained has theoretical meaning as the Hicksian compensating variation. (a) Thus, sinden concluded that the use of the direct inquiry method for estimating utility functions and eventual social valuation was superior to, the traditional travel cost methods for valuing recreation experiences.

\section{Direct Bid Approach}

Bradford (1970) rejected the traditional private market proxy and utilitydemand approaches to valuing externalities. He argued that use of demand curves is inappropriate for valuing externalities, because the value of an externality is determined through each individual's evaluation of a bundle of goods, rather than by their responses to a price per unit of a good. Because people cannot purchase units of an externality, Bradford concludes that demand curves for externalities are conceptually impossible.

Bradford bid curves are indifference curves passing through the individual's initial welfare position. They represent an individual's indifference between changes in the level of the externality and the corresponding change in wealth which equals an individual's bid. An aggregate bid curve can be derived by adding all individual bid curves

(a) This is defined as the amount of compensation that will leave the consumer in his initial welfare position following a change in price if he is free to buy any quantity of the commodity at the new price. 
vertically for the relevant population. The aggregate bid curve provides a measure of the social value associated with a change in the amount of an externality. The net result of the bidding game is this aggregate bid curve showing the social value of all relevant changes in the level of an externality.

Bidding games use direct inquiries to induce people to reveal their true values. Individuals are presented information about alternative levels of externalities. They are then asked one of four types of questions:

(1) "Assuming you are entitled to your current situation, how much would you be willing to pay to have more of a positive externality?"

(2) "Assuming you are entitled to your current situation, how much would you be willing to accept in compensation to allow more of a negative externality?"

(3) "Assuming you are entitled to more of a negative externality, how much would you be willing to pay to avoid this situation?"

(4) "Assuming you are entitled to more of a positive externality, how much would you be willing to accept in compensation to forego this situation?"

These four questions yield the following measures of value, respectively:

(1) compensating measure of willingness to pay,

(2) compensating measure of willingness to accept compensation,

(3) equivalent measure of willingness to pay, and

(4) equivalent measure of willingness to accept compensation.

Which of these four. measures of value is relevant in a particular instance depends on (a) whether the individual is entitled to his initial welfare position, and (b) whether the externality has positive or negative value to him (Randall (1977)). If the individual has a right to his initial welfare position, then the compensating measures are the correct measures of value. If he has no right to his initial welfare position, then the equivalent measures are the correct measures of value. The equivalent measure of willingness to pay and the compensating measure of willingness 
to accept compensation are the correct measures of the value of a negative externality. Similarly, the compensating measure of willingness to pay and the equivalent measure of willingness to accept compensation are the correct measures of the value of a positive externality.

Consider, for example, a bidding game associated with a negative visual impact from a power plant on a community where the intruding party has the right to alter the current state. The game would begin by asking a member of this community, "Would you be willing to have your electric bill increased by $X$ dollars to prevent the visual intrusion?" An increase in the individual's electric bill is used to make the trade-off more realistic. (0ther possible payment vehicles include contributions to an environmental fund, changes in sales or property taxes, and recreational user fees.) Following an affirmative response, the next question raises the ante: "Would you be willing to have your electric bill raised $X+1$ dollars to prevent the visual intrusion?" As long as the respondent continues to respond in a positive manner, the ante is raised by a constant amount (\$i in this exampie) until a negative response is gained. Following this negative response, the ante is decreased by a smaller amount than it was being increased by ( $\$ 0.25$ for example) until the first positive response is made.

If the individual has rights to his current state of visual aesthetics, the imposing party must bid away this right. In this case, the social value measurement is made by asking the individual "Would you be willing to accept a reduction of $X$ dollars in your electric bill to allow the visual intrusion?" The procedure then follows a format similar to the willingness to pay case until the highest positive response is recorded.

Because the bidding game is a method of collecting survey data, it is subject to the same potential sources of error inherent in any survey technique including:

- A bidding game has a certain degree of artificiality about it. Can we be assured that a person will take the endeavor seriously enough to actually sort out his true feelings and preferences? 
- Even if individuals do take the procedure seriously, they have incentives to bias answers to questions which are intended to elicit individual bids. By intentionally over- or understating their bids, individuals could affect the social valuation of the impact.

- A respondent's final bid may depend upon the starting point. For example, if the first question were "Would you be willing to accept $\$ 10$ ?", a different final outcome could result than if the first question were "Would you be willing to accept $\$ 1,000$ ?"

- The respondent may feel somewhat overwhelmed in the interview because of the context surrounding the process. This may lead the respondent to attempt to please the interviewer and thereby, ignore his true preferences during the interview process.

Most of these problems can be alleviated with careful experimental design and sampling procedures. The importance of these potential sources of error has not been established in the literature.

While the direct bid approach is subject to potential biases because of its use of survey data, it is the most flexible and potentially comprehensive technique also. Using the direct bid approach it is possible to estimate the value of the specific combination of consequences in question rather than looking for as similar a case as possible in people's experiences. Bidding games also allow valuation of situations people have not yet experienced.

\section{INTEGRATING DOLLAR MEASURES OF VALUE.}

Once the consequences of each alternative decision have been valued in dollar units, they must be compared in a way which will yield the recommendation of one of the alternatives over the others. The preferred method for doing this is to select the alternative which has the largest net present value defined as follows:

$$
P V=\sum_{t=0}^{n} \frac{B_{t}-C_{t}}{(1+r)^{t}}
$$


where

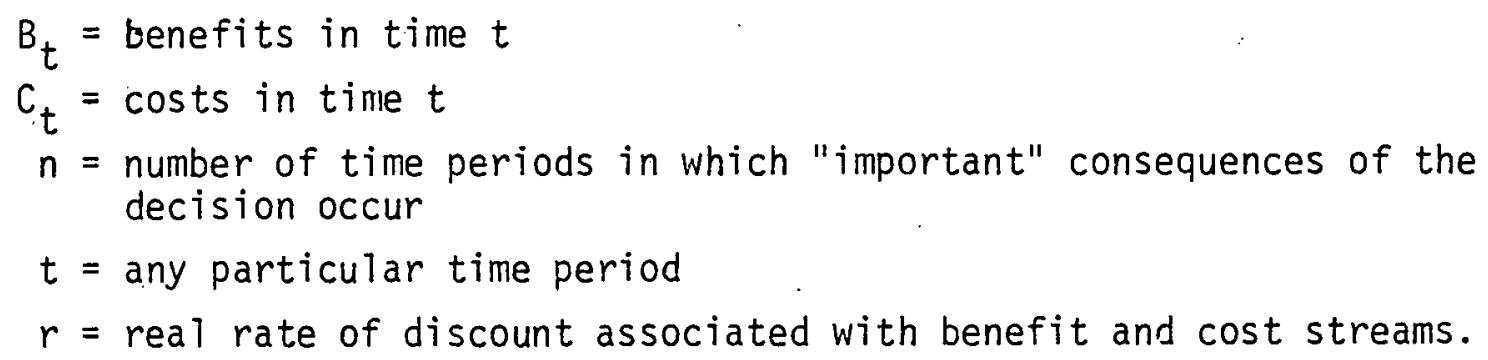

However, in order to avoid favoring expensive projects over smaller alternatives, one must first equate the marginal benefits and marginal costs of each alternative, and then select the alternative with the greatest net difference between total benefits and total costs. Using this criteria the marginal benefit produced by the last dollar. of expenditure on all projects and for all purposes is equal at the optimum and the total benefits exceed the total cost in each application. This choice is also supported in the legal history of benefit-cost analysis by what is known as Senate Document 97 (1962).

Eckstein (1958) discusses this and other approaciles to comparing benefits and costs. Often the alternative with the largest ratio of present value of benefits to present value of costs has been selected. However, this procedure does not necessarily maximize net benefits or equate the marginal benefits and marginal costs of each alternative.

Another approach is to select the alternative with the highest "internal rate of return." The internal rate of return is defined as that rate which makes benefit and cost streams equal in present value terms. This selection criteria has three major deficiencies: 1) This approach assumes that any returns which occur during the 1 ife of the project are reinvested at the same internal rate of return. 2) It may not select the alternative which would lead to the greatest improvement in allocative efficiency when the duration of the time streams of benefits and costs differ. For example, it would not necessarily maximize investment returns to select a project with a very high rate of return, if it is a short lived project and the alternative reinvestment possibilities for the funds after this period are very low compared to a longer lived project in which investment could be 
made over the entire period. 3) The internal rate of return is not necessarily unique for a given alternative; i.e., in some cases, there can be more than one rate of return which makes the net present value equal to zero. Uniqueness occurs with a conventional benefit stream of negative net benefits in the early years but positive net benefits in the latter years. However, for a decision involving negative net benefits in the early years, positive net benefits in the middle years and negative net benefits in the latter years, the internal rate of return may not be unique. Examples of this type of benefit stream are the opening, mining and closing of a coat mine or the construction, operation and decommissioning of a nuclear power plant. (See Herfindahl and Kneese (1974) for a discussion of thi.s topic.)

Selection of the Discount Rate

We turn now to perhaps the most difficult issue involved in comparing benefits and costs: selection of the discount rate. The two factors which are most significant in selecting the discount rate for the problem at hand are the rate of time preference and the opportunity cost of capital.

The rate at which people are willing to trade current income for future gains is termed their "rate of time preference". Individual rates of time preference are probably positive. Suppose, for example, that the only difference between two alternative investment opportunities for which identical costs would be incurred in the present period is that the beneficial returns to one of these investments would accrue one year from now while the other would accrue ten years from now. The fact that most people would prefer the investment opportunity with the earlier return is evidence that most people have positive rates of time preference.

Suppose that a person must be offered $(T+R)$ dollars one year from now to be willing to give up one dollar today, then one dollar next year would be worth $(1 /(T+R))$ dollars to him today. Generalizing this, we can say

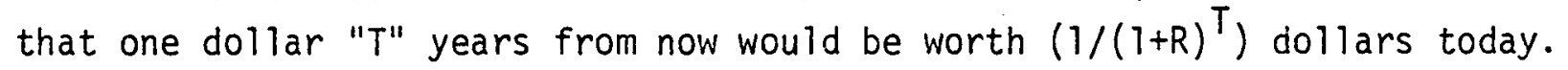
This expression is termed a "discount factor" which is used to reduce future benefits and costs to their "present value." The "R" in this expression is called the "discount rate." 
The rate at which people are able to trade current income for future gains is called their "opportunity cost of capital." Under certain conditions, this private opportunity cost of capital would equal the riskless market rate of interest. These conditions are no taxes on income from capital or on yields from savings and no risk. Under these conditions, individuals would adjust their rates of borrowing and lending so that their rate of time preference was equal in equilibrium to the riskless market rate interest. When such taxes exist, the social opportunity cost of capital wi1l exceed the private opportunity cost of capital and the private rate of time preference by the amount of the taxes. When individuals make private investment decisions under these circumstances, they will equate their after tax opportunity cost of capital with their private rate of time preference because this will maximize the present value of their income stream over time, given their preferences and the existence of the taxes.

When an individual performs a benefit-cost analysis of a private investment decision, he should use the after tax nominal or market rate of interest for equally risky investments as a discount rate if he also measures the benefits and costs in nominal or inflated dollars. However, if he measures the benefits and costs in real or constant dollar terms, then the "reai rate of interest" would be the appropriate measure of the opportunity cost of the funds to be employed. The nominal or market rate of interest is (approximately) equal to the real rate of interest plus the expected rate of inflation; therefore, the two rates would be equal if no inflation (or deflation) were expected. Most economists think that the real rate of interest is probably $2 \%$ or $3 \%$ (Arrow (1976)).

One could use the market rate of interest as the discount rate for public decisions having intertemporal impacts measured in nominal dollar terms when the private and social rates of time preference and the private and social opportunity costs of capital are all equal. However, these conditions would exist only if there were no taxes on income from capital or on yields from savings and if there were no market failures anywhere in the economy. 
The dilemma is how to select an appropriate discount rate for such public decisions when such taxes and market failures do exist. There has been a lengthy debate in the economics literature on this question. On the one hand, the use of a discount rate less than the before tax or social opportunity cost of private investments could produce public projects which yield less than the foregone private alternatives (Hirshleifer $(1965,1966)$ ). On the other hand, the use of a discount rate different from the social rate of time preference will not maximize social welfare (Marglin (1963)).

Actually, both the social opportunity cost of capital and the social rate of time preference are important determinants of the social rate of discount. Sjaastad and Wisecarver (1977) show that the social rate of discount is a weighted average of the social rate of time preference and the social opportunity cost of capital. The weights are the fractions of each dollar of public investment which takes place at the expense of private consumption and investment, respectively. In particular

$$
\omega=\theta p+(1-\theta) r
$$

where

$$
\begin{aligned}
& \begin{array}{l}
\omega=\text { social rate of discount } \\
\rho
\end{array}=\text { social opportunity cost of capital } \\
& r=\text { social rate of time preference } \\
& \theta=\text { fraction of public investment which displaces private investment } \\
& (1-\theta)=\text { fraction of public investment which displaces private consumption. } \\
& \text { In actually estimating the social rate of discount, w, to be used in } \\
& \text { a benefit-cost analysis of a public decision, one must estimate the social } \\
& \text { Much of the literature on selection of a social rate of discount can } \\
& \text { actually be seen as discussions of the reasons for divergences between the } \\
& \text { private and social opportunity costs of capital and between the private and } \\
& \text { social rates of time preference as reasons for the divergence between } \rho \text { and } r \text {. }
\end{aligned}
$$


As we have already seen, the social opportunity cost of capital exceeds the private opportunity cost of capital by the extent of any taxes on income from capital or on yields from savings. There has been considerable discussion in the literature on the issue of whether any differences in the treatment of risk between public ard private investments would tend to offset this. While the government may have some advantages in spreading risk over a large number of investments (Samuelson (1964)) and over a large number of people (Arrow and Lind (1970) and Hirshleifer and Shapiro (1970)), these results hold only when considering public investments which produce private goods (Fisher (1973)). For public decisions involving public goods, such as power plant siting decisions whose goal is to minimize the total social costs of electricity production, the inclusion of risk premiums is relevant to determining the social opportunity cost of capital. Thus, the before tax market rate of interest for equally risky decisions is the social opportunity cost of capital for public decisions whose benefits and costs are valued in current year dollars.

The social rate of time preference, $r$, may be below the private rate of time preference because of intertemporal externalities (Marglin (1963)). People may today place some value on what people decades from now (not necessarily their descendants or even individuals currently identifiable have to consume. That is, there are intertemporaliy or intergenerationally interdependent utility functions. However, the social rate of discount may be above the private rate if future generations are expected to be richer than present society and if there is decreasing marginal utility of income in both periods (Tullock (1964)). Which of these effects dominates is an empirical question which has not been answered. If the size of these externalities were known, then public policy to internalize them should impact public and private investment decisions in the same way (Baumol (1968)). However, the decision to use the mechanism of adjusting the discount rate would probably be based more on practical than efficiency grounds; it would be coincidental to have the mathematical form of the discounting adjustment correspond to the adjustment of benefit and cost measures in each time period necessary to internalize these externalities. 
There are other important intertemporal and especially integenerational effects which should not necessarily be incorporated through modifying the discount rate. Some people may argue that environmental and health effects should not be discounted; i.e., a zero discount rate should be used. However, the problem may be that the impacts which anticipation of future events can have on the current well being of individuals have been ignored (Schelling (1968)). Such anciety about future possible events has the impact of moving to the present some multiple of the future value of these events. This shifts the time distribution of impacts toward the present and increases the present value of the events. However, it may not be appropriate to incorporate such effects into the discount rate.

$\hat{A}$ related conceptual problem is that of "irreversibility," especially in case of environmental and health effects of electricity production. An action is said to be "irreversible" if costs of undoing the action far exceed the benefits. This can be significant if the relative values of health and environmental impacts rise over time with incomes. A complicating problem is that one may not be certain that an action is irreversible at the time of the decision. Thus, an important element is peoples' attitudes toward living with the consequences of decisions which may later be shown to have been irreversible. Again, it may not be appropriate to lower the discount rate to take these other intertemporal effects into account, however (Baumol (1968) and Krutilla and Fisher (1975)).

In this section we have seen that benefit-cost analysis differs from multi-attribute utility analysis. in that it values all consequences of the alternatives in dollar units. Private market prices may be directly used to value some benefits and costs. However, because of market failures many benefits and costs relevent to public decision problems cannot be accurately valued by directly using private market prices. These market failures may involve either imperfectly competitive markets or externalities. When such market failures exist, other methods must be used to obtain dollar measures of value. In some cases observed behavior may be used to infer the value of benefits and costs to people. An alternative to the use of such private market proxies is the use of direct inquiries, either to estimate utility 
functions and derive demand curves from them to obtain a consumers' surplus measure of value or to directly estimate equivalent or compensating measures of value using bidding games. We have also seen that a key factor in comparing benefits and costs once they have been valued in dollar terms is the selection of the discount rate. To select the discount rate for publ ic investments one should look at the social rate of time preference and the social opportunity cost of capital. However, it is not necessarily appropriate to take into account all intertemporal effects through the use of the discount rate. Significant effects with should not necessarily be incorporated in the discount rate include risk premiums, anxiety in the present about future consequences of a decision, and inter.temporal changes in the relative value of consequences. In the next section we see how multi-attribute utility analysis has developed procedures for performing integrative assessment of public decisions without valuing all consequences in dollar terms. 


\section{IUUTI-ATTRIBUTE UTILITY ANALYSIS}

Multi-attribute utility analysis is very similar to benefit-cost analysis theoretically and conceptually. Having discussed the common features of these integrative assessment methodologies in the second section, we will focuss here on features of multi-attribute utility analysis which distinguish it from benefit-cost analysis. The most obvious distinction between multiattribute utility analysis and benefit-cost analysis is the units in which the values of all the consequences of the identified alternatives are measured; multi-attribute utility analysis measures these values in units called "utils." Thus, in multi-attribute utility analysis the estimation of utility functions is not an intermediate step to the derivation of dollar measures of value as is the case of the utility demand approaches sometimes used in benefit-cost analysis. Rather, the util measures of value are directly munipulated to arrive at the recommendation of one of the alternatives.

While multi-attribute utility analysis is theoretically and conceptually very similar to benefit-cost analysis, there have been significant differences between the two approaches in the application of this theory to practical problems. The first of these major practical differences involves the method of utility or value estimation. Multi-attribute utility analysis relies on direct inquiry approaches to value estimation much more heavily than has traditionaliy been the case with benefit-cost analysis. The major reasons for the use of primary survey data have been the ability to include nonlinear utility functions and attitudes toward uncertainty. This use of direct inquiry approaches to value or utility estimation make multi-attribute utility analysis most similar to the direct bid approaches which are being increasingly used in benefit-cost analysis.

Similarly, the other differences in practical application between multi-attribute utility analysis and benefit-cost analys is need not remain differences. These common differences in application include: 1) differences as to whose values are estimated, 2) differences in approach to incorporating uncertainty, and 3) differences in approach to intertemporal comparisons. Before turning to discussion of these differences in practical application, we will briefly discuss the alternative scales in which utility could be measured. 


\section{ALTERNATIVE UTIL SCALES}

Utility functions are a theoretical construct which can be operationaliy estimated using any units or scales which the analyst may select. There are several alternatives available to the analyst including ordinal, interval, and ratio or cardinal scales. Ordinal scales are the easiest to estimate since they require merely the ranking of the consequences being valued. While ordinal rankings are unchanged by the application of any monotonically increasing function, the numbers obtained in an ordinal ranking cannot be algebraicly manipulated. Interval scales are more difficult to obtain, but also permit the analyst to infer more from data measured in such scales. With interval scales the distance between each element on the scale has meaning. The operations necessary to incorporate uncertainty into the analysis, such as construction of an arithmetic mean and standard deviation, require an interval scale. Ratio or cardinal scales are necessary to give meaning to ratios of differences between utilities of goods. A ratio scale thus has all the properties of an interval scale but in addition has an absolute zero reference point; this allows us to speak of percent variation in utility estimates; for example (Green (1971); also see Stevens (1959) for more on properties of measurement scales)).

While utils as an arbitrary utility scale may refer to any of these alternatives, the utils used in multi-attribute utility analysis generally have the properties of an interval scale. Dollars, on the other hand, are a ratio or cardinal scale. Thus, purely on the difference of the type of scale generally obtained, dollar measures are more difficult to obtain but also allow the analyst to perform some operations which are inadmissable using interval util scales. Utils could be measured on a cardinal or ratio - scale, but generally have not been in multi-attribute utility analyses.

\section{VALUING CONSEQUENCES IN UTILS}

In multi-attribute utility analysis direct inquiry methods are used to value consequences of the alternatives under consideration. Private market prices are not generally used as a measure of value because of concern over the existence of market failures disclissed in the previous chapter. Indirect 
use of private market prices to construct private market proxies is also avoided. The latter technique is not used primarily because of concern that the set of conditions surrounding the alternatives under consideration are too different from any conditions which existed in the past to allow historical data to be relevant.

The direct inquiry methods of valuing consequences have encouraged those using multi-attribute utility analysis to include a smaller number of individual's values in the analysis. Frequently the individual responsible for making the decision in question has been directly interviewed and his values have been assumed to be those relevant to the decision at hand. In fact, the emphasis in multi-attribute utility analysis has historically been on aiding decision makers to explore and understand their own preferences. In any given public decision problem it may or may not be appropriate to assume that the decision maker has values identical to those of the parties who may be impacted by the decision. In any case, this historical emphasis on use of decision makers values in multi-attribute utility analysis is no more a theoretical limitation on the method than has been the extensive use of private market prices in the face of market failures in benefit-cost anaiysis.

The direct inquiry method selected to value consequences in a multiattribute utility analysis depends partly on the approach selected to incorporate uncertainty. If the effects of risk and uncertainty on the decision are considered negligible or if one is willing to use expected values in the analysis then either paired comparisons or direct scaling methods may be used. If one is not willing to make these assumptions then lottery methods are selected.

\section{Paired Comparisons}

In the method of paired comparisons the interviewer begins by asking the person or group whose values is considered relevant to the analysis (hereafter called the interviewee) to rank the consequences of each alternative according to their relative desirability. The interviewee is then asked 
to make paired comparisons between adjacent items on this ordinal scale. By indicating how much better he likes one item on the list compared to the adjacent item the interviewee transforms tris ordinal ranking of consequences to an interval scale.

\section{Direct Scaling}

Direct scaling methods require the interviewee to directly and in one step state his preferences on the scale which will be used in the analysis. This could involve rating consequences on scales from one to ten, placing consequences in relative positions on a graph, or assigning numerical scores to consequences. These direct scaling methods could-thus measure utility. on any of the alternative util scales discussed in the previous section. As with all questionnaires, the wording and ordering of the questions could affect the responses (Fischhoff, et al. (1977)).

\section{Lottery Methods}

When there is significant risk or uncertainty regarding the consequences of the alternatives under consideration one must decide whether it is reascnable to assume that the persons whose values are relevant to the decision at hand are "risk neutral". People are said to be risk neutral when their utility of the expected consequences is equal to their expected utility of the consequences. This would exist when an individual is indifferent between two alternatives having the same expected consequences but where the consequences of one alternative are certain to occur and the consequences of the other a) ternative are not.

When the analyst suspects that the interviewee is not risk neutral, lottery methods can be empolyed to derive utility functions. (von Neumann and Morgenstern, 1947). By using these lottery methods it is possible to derive the expected utility of the uncertain combination of consequences by measuring both the interviewee's. attitudes towards risk and his relative 
value of the consequences simultaneously. (These lottery methods have also been used in benefit-cost analysis. See page 17 above.)

Three types of lottery questions may be employed in the process of estimating the interviewee's utility function (Keeney and Raiffa, 1976): (1) the interviewee can be asked whether he prefers $X$ for certain or a $50 / 50$ chance of $(X+H)$ and $(X-H)$. If he is indifferent between the two, he is said to exhibit risk neutral behavior; if he prefers the certain outcome, he is said to be risk averse; if he prefers the uncertain outcome, he is said to prefer risk. Thus, the answers to this question establish the shape of the utility curve. (2) The interviewee may be asked to compare a $50 / 50$ chance of consequences $X^{\prime}$ and $X^{\prime \prime}$ with various certain outcomes. This process is continued until a certain outcome, $X$, is found which the interviewee values as equivalent to the lottery. This establishes a point between $X^{\prime}$ and $X "$ on the interviewee's utility curve. (3) The interviewee may be asked to make choices between various certain outcomes and lotteries involving various probabilities of occurrence of $X^{\prime}$ and $X^{\prime \prime}$. Responses to such questicns can determine additional intermediate values of consequences, $X$, between $X^{\prime}$ and $X^{\prime \prime}$. and thus trace out a range of the utility curve of the interviewee, assuming the interviewee does not prefer some probabilities for their own sake.

The use of lottery methods to incorporate the interviewee's risk preferences in the assessment of his value of the consequences of the alternatives under consideration requires significant additional effort for both the analyst and the interviewee. However, the additional information obtained can often improve the integrative assessment. In benefit-cost analysis such lottery methods of assessing utility functions have been used less frequently than in multi-attribute utility analysis; risk and uncertainty have been considered more frequently in multi-attribute utility analys is than has historically been the case in benefit-cost analysis. 
If uncertainty regarding both the consequences and their value exist then computer simulations using Monte Carlo techniques may be required. Special statistical techniques may be required to compare the resulting distributions of relative value for each alternative (Litchfield, et al. (1975)).

\section{INTEGRATING UTIL MEASURES OF VALUE}

Once the consequences of the available alternatives has been valued in util terms one must combine and compare the values to arrive at the recommendation of one of the alternatives. In order to be able to meaningfuily compare the sum of the values of the consequences of each alternative the following assumption must hold. The value of each consequence is assumed to be independent of the extent of all other consequences. In other words, the consequences are stated in a way which allows one to assume that they are value independent. If this assumption holds, then it is meaningful to simply add the values of all the consequences of each alterrative to obtain the value in util terms of each alternative. The alternative with the highest util value is then recommended.

When preliminary questioning indicates that the consequences cannot be assumed to be value independent, a scaling constant must be used for every combination of value dependent consequences. The direct inquiry method of paired comparisons may be used to derive these scaling constants. The number of value dependent consequences is made as small as possible by the way in which the consequences of the alternatives are described.

\section{Intertemporal Comparisons}

In the above description of methods for integrating the util measures of the value of the consequences of each alternative, we have implicitly assumed either that all consequences occurred in the same time period or that they had been reduced to units of value which did occur in the same time period. When 
all consequences of the decision occur in the same time period or are the same for all successive time periods, then no intertemporal comparisons are necessary. Most public decisions involve differing consequences in each period, and thus intertemporal comparisons become very important. Four major approaches have been used for making intertemporal comparisons: (1) the use of discount rates; (2) defining separate consequences for each time period; (3) assessing preferences for a scenario which consists of a distribution of consequences over time; and (4) expressing the consequences in annualized terms.

An implicit discount rate for a consequence can be assessed by developing a utility function for a consequence over time (Keeney and Raiffia (1976)). Conceptually this time dependent utility function contains a discount rate; however, it also encodes the attitudes of the interviewee towards the uncertainty of when consequences may occur. This approach requires a great deal of effort, essentially doubling the number of utility functions that must be assessed. An excellent survey of forms of utility functions and applications incorporating differing time preferences appears in Fishburn (1968). Rowe (1977) assesses differing societal discount rates for long-term health risks, short term health risks, and irreversible commitments by examining statistics of current behavior.

If consequences occur in a few distinct time periods, then a separate consequence can be defined for each period (Litchfield, et al. (1975)). For example, one may define water quality associated with a construction project by two consequences: (1) water quality during construction; and (2) water quality after construction. Similarly, one can define short-term and long-term health effects as two consequences for storing wastes. In general, this approach assumes that the consequences are evenly spread over the time period.

When the consequences are not evenly distributed over time periods, one can assess preferences for scenarios which present differing distributions of consequences over time (Baecher, et al. (1975)). The scenarios can be directly 
rated or a certainty equivalent can be assessed. The certainty equivalent may be either the immediate consequence or a consequence of the same magnitude occurring each year over the decision horizon which is equivalent to the probabilistic distribution of consequences over time presented in the scenario.

In some cases it may be reasonable to assume that the consequences have the same probability distribution for each period. In this case the consequence is defined in terms of annual impacts and the interviewee's utility function is assessed for consequences per year for the horizon of the decision problem (Kreps (1975) and Nair, et al. (1976)). The interviewee implicity supplies the discount rate in this approach.

In this section we have seen that multi-attribute utility analysis measures the value of the consequences of the alternatives in units called utils. These measures of value are obtained through various direct inquiries of the individual whose values are considered relevant to the decision in question. These methods of direct inquiry include paired comparisons, direct scaling and lottery methods. We have also seen that uncertainty is more frequentiy taken into account in the use of this value estimation procedure in multi-attribute utility analysis than has traditionally been the case in berefit-cost analysis. Also, the method of inter-temporal comparison of the measures of value obtained for consequences occuring in different time periods is more frequently performed through additional direct inquiry rather than through the use of a discount rate. Finally, the use of direct inquiry methods has encouraged the inclusion of a smaller group's values in multi-attribute utility analysis than is claimed for benefit-cost analysis, which has traditionally employed other techniques of value estimation. 
In the second section we saw that the key factor determining whether benefit-cost analysis or multi-attribute utility analysis should be selected to perform an integrative assessment is whether the boundary of the analysis has been defined to include "important" consequences which it is felt cannot be accurately valued in dollar terms. This is because the key feature distinguishing benefit-cost analysis from multi-attribute utility analys is is that all the consequences are valued in dollar terms in the former and in util terms in the latter.

Dollars are a cardinal measure of value while utils are usually an interval measure of utility or value. Both measures allow the decision maker to see the extent to which the recommended alternative is preferred to other alternatives. The interval util measure is easier to obtain in an interview setting since it does not require people to compare the consequences of all the alternatives under consideration with other things in the interviewee's environment. However, utils are an arbitrarily chosen unit of value which is specific to the analysis conducted. On the other hand, money is a common and readily understood unit to which people can easily relate. Also, the dollar measure of value allows comparison of the vaiue obtained for the alternatives with other things in the environment. These differences in the units of value used in benefit-cost and multi-attribute utility analysis are the only necessary differences between these integrative assessment methodologies.

\section{VALUE ESTIMATION}

There are, however, several differences in application which have historically existed between benefit-cost analysis and multi-attribute utility analysis. For example, multi-attribute utility analysis has historically relied more heavily on direct inquiry methods of value estimation than has benefit-cost analysis. However, the use of bidding games to estimate the value of goods for which private markets do not exist is increasing in benefitcost analysis. 
If there were no market failures, benefit-cost analysis could use market prices exclusively to measure the social value of the consequences of various alternatives. Thus, benefit-cost analys is is capable of quicker and cheaper results than would be possible if it were necessary to estimate the value of the consequences using direct inquiry techniques. However, the values of some important effects are difficult to measure. For example, the environmental impacts and heal th effects associated with alternative locations of a power plant may be much more difficult to value in dollar terms than the capital and operating costs of the plant. In benefit-cost analysis many techniques have been used to value environmental and health effects in dollar terms. In multi-attribute utility analysis all-of the effects including environmental and health effects are valued in util terms. Because all measures of utility or value are subject to some potential sources of bias, it is not possible to state in general which methods of value estimation may be more subject to error.

In benefit-cost analys is the stress has been on finding which of the alternatives for a public decision would lead to the greatest increase in social welfare. In multi-attribute utility analysis the emphasis has been on aiding the decision maker to understand the implications of his own preferences for making decisions. The difference in emphasis may be largely attributed to the historical difference in the method of value estimation noted above. This is because a key factor determining the expense of implimenting a direct inquiry method of value estimation is the sample size. However, this historical difference as to whose values are included in the analysis is not a necessary difference between the two methodologies. In fact, it is a difference which is declining in importance.

\section{UNCERTAINTY}

Uncertainty can be incorporated into both methodologies in two basic ways. The first is based on a "lottery" technique. This technique estimates the value of uncertain consequences in terms of certainty equivalents. 
A second approach to incorporating uncertainty in integrative assessments estimates both the consequences and their value as stochastic variables. These estimates commonly manifest themselves as probability density functions and can be mathematically combined resulting in a single probability density function for each of the alternatives. Statistical theory then provides several . alternative approaches for ordering probability distributions. As a result of using this approach, uncertainty in the estimates of both the consequences and their value can be incorporated explicitly into the relative value measures of the alternatives.

Multiattribute utility analysis has devoted more attention to the incorporation of uncertainty than has benefit-cost analysis; the reverse is true of intertemporal comparisons.

\section{INTERTEMPORAL COMPARISONS}

In benefit-cost analysis, the values of consequences occurring in different time periods are first valued in each time period and then compared across time periods through the use of a discount rate. As we saw in Section III, the social rate of discount can be selected by looking at the social opportunity cost of capital and the social rate of time preference.

While multiattribute utility analysis has devoted less attention to intertemporal comparisons, its approaches to comparative valuation of time dependent effects have included (1) assuming that each consequence has the same value for each period, (2) directly assessing valuations for an assumed distribution of consequences over time, and (3) specification of separate consequences in each time period. Thus, multi-attribute utility analysis makes less explicit use of the discounting approach. The values of distant consequences are sometimes directly and simultaneously estimated and compared with the values of less distant consequences rather than estimating the value of the consequences in each time period and then discounting these values to obtain a present value of the consequences as is done in benefit-cost analysis. 


\section{ASSUMPTIONS}

Multi-attribute utility analys is assumes that the consequences are specified so that they are value independent. With the value independence assumption the generalized shape of the utility curve on any one consequence can be indepenciently estimated without specific information on the extent of any of the other consequences. These utility functions can be any monotonic function. When the consequences are not vaiue independent, one must use nonlinear combinations of the value of consequences, such as multiplicative utility functions, for determining the total utility or value of each alternative. While these functions correct for the vallie interdependencies among the consequences, they require additional value information from the relevant social group.

Benefit-cost analyses generally assume that only marginal changes will result from the adoption of any one of the available alternatives. By assuming that only marginal changes occur from existing conditions, it is possible to assume that the effects of any interdependence of the value of some consequence on the extent of other consequences and on existing conditions of the environment of persons whose values are being estimated, do not significantly affect the values of the benefits and costs as measured. If nonmarginal changes do occur, it is possible to estimate the interdependencies and their impact.

Both approaches generally assume that the distribution of consequences among different social groups can be balanced by other actions. Economists have demonstrated that where the total benefits to society exceed the costs, compensation schemes are possible which can convert this situation into one where some persons or groups gain and no persons or groups lose and thus where social welfare is clearly increased. Thus, it is possible to deal with the question of distributional equity by suggesting schemes in which those who gain by the selected alternative compensate those who lose. If one could determine the value of equity considerations to the $\operatorname{aroup}(s)$ whose values are considered relevant and if inter-group comparisons could be made, it would be possible to incorporate these effects more explicitly into the analysis. However, the information necessary to make the interpersonal comparisons is generally unavailable. 
It should be stressed that regardless of which integrative assessment methodology is selected for a given application, one integrative assessment methodology must be chosen. One should not perform benefit-cost analysis for one portion of an integrative assessment and multi-attribute utility analysis for another portion because it would not be possible to integrate such partial analyses in a meaningful way. Neither approach is clearly superior for all applications, but a single approach must be selected for each integrative assessment. 


\section{REFERENCES}

Arrow, Kenneth J., "The Rate of Discount for Long-Term Public Investment." Energy and the Environment: A Risk Benefit Approach, H. Ashiey, R. L. Rudman and C. Whipple, eds., Pergamon Press, NY, p. 118, 1976.

Arrow, K. J. and Lind, R. C., "Uncertainty and the Evaluation of Public Investment Decisions." Amer. Econ. Rev. 60, June 1970.

Baecher, G. B., et. al., Balancing Apples and Oranges: Methodologies for Facility Siting Decisions, International Institute for Applied Systems Analysis, Schloss Laxenburg, Austria, A-2661, September 1975.

Baquet, Alan E., An Economic Evaluation of Frost Forecasting in Jackson County. M.S. thesis, Oregon State University, 1974.

Baumo1, W. J., "On the Social Rate of Discount." Amer. Econ. Rev., Sept. 1968.

Bradford, D. F., "Benefit-Cost Analysis and Demand Curves for Public Goods." Kyklos 23:775-791, 1970.

d'Arge, Ralph C., "Introduction and Overview," Economic and Social Measures of Biologic and Climatic Change. A. J. Grobecker, ed., DOT-TST-75-56, Washington, D.C., Sept., 1975.

Eckstein, .0., Water Resource Development -- The Economics of Project Evaluation. Harvard University Press, Cambridge, MA, 1958.

Environmental Protection Agency, First Year Work Plan for a Technology Assessment of Western Energy Resource Development. EPA-600/5-76-001, University of Oklahoma, Norman, OK, March 1976.

Erickson, L.E., A Taxonomy of Market Failures. BNWL-SA-6286 (Draft), Battelle, Pacific Northwest Laboratories, Richland, WA, 1977.

Fischhoff, B., P. Slovic, and S. Lichtenstein, "Behavioral Aspects of CostBenefit Analysis," Proceedings of a Workshop on the Measure of Intangible Environmental Impacts. Electric Power Research Institute, Ralo Alto, CA, EPRI EA-405-SR, March 1977.

Fishburn, Peter C., "Utility Theory," Management Science, Vol. 14, No. 5, January, 1968.

Fisher, A.C., "Environmental Externalities and the Arrow-Lind Public Investment Theorem." Amer. Econ. Revlew, Sept. 1973.

Freeman, A. M., III, "On Estimating Air Pollution Control Benefits From Land Value Studies." J. Envir. Econ. 1:74-83, 1974.

Green, H. A. John, Consumer Theory, Penguin Books, Baitimore, MD, 1971.

Greenhut, M. L. and Ohta, H., Theory of Spatial Pricing and Market Areas. Duke University Press, Durham, N.C., 1975. 
Harberger, A. C., Project Evaluation, Collected Papers. Markham Press, Chicago, IL, 1973.

Herfindah1, 0. C. and Kneese, A. V., Economic Theory of Natural Resources. Charles E. Merril1, Columbus, OH, 1974.

Hirschleifer, J., "Investment Decision Under Uncertainty: Choice-Theoretic Approaches." Quarterly Journal of Economics, 79:509-536, Nov., 1965.

Hirschleifer, J., "Investment Decision Under Uncertainty: Applications of the State-Preference Approach." Quarterly Journal of Economics, 80:252-277, May 1966.

Hirschleifer, J. and Shapiro, D. L., "The Treatment of Risk and Uncertainty," Chapter 11 of Haveman, R. H. and Margolis, J., Public Expenditure and Policy Analysis, Markham, Chicago, 1970.

Keeney, R. L. and H. Raiffa, Decisions with Multiple Objectives: Preferences and Value Tradeoffs. John WiTey and Sons, New York, 1976.

Kreps, D.M. Markov Decision Problems with Expected Utility Criteria, I: Basic Notions and Essentially Positive, Essentially Negative and Convergent Utility, Graduate School of Business, Stanford University, Palo Alto, California, Research Paper No. 266, July 1975.

Krutilla, John V. and Fisher, Anthony C., The Economics of Natural Environments: Studies in the Valuation of Commodity and Amenity Resources. Published for the Future, Inc. by Johns Hopkins University Press, Battimore, MD, 1975.

Litchfield, J. W., J. V. Hanson, and L. C. Beck, A Decision Model Incorporating Utility Theory and Measurement of Social Values Applied to Nuclear Waste Management. BNWL-B-424, Battelle, Pacific Northwest Laboratories, Richland, WA, Ju1y 1975 .

Mäler, Karl-Göran, "Property Values and Damage Functions." EPRI: Proceedings of a Workshop on the Measure of Intangible Environmental Impacts, Special Report, March 1977.

Mäler, K.-G., "Approaches Based on Individual Behavior." EPRI: Proceedings of a Workshop on the Measure of Intangible Environmental Impacts, Special Report, March 1977.

Marglin, S., "The Social Rate of Discount and the Optimal Rate of Investment." Quarterly Journal of Economics, February 1963.

Mishan, E. J., Cost-Benefit Analysis. Praeger Publ., NY, 1976.

Nair, K., Sicherman, A., Merino, J.M., "Environmental Impact Assessment Methodology for Energy Conversion Systems," presented at ANS Topical Meeting on Environmental Aspects of Non-Conventional Energy Resources, Denver, C0, March 1-3, 1976.

Neuman, J. Von and 0 . Morgenstern, Theory of Causes and Economic Behavior. 2nd Edition, Princeton University Press, Princeton, NJ, 1947. 
President's Water Resources Council, "Policies, Standards, and Procedures in the Formulation, Evaluation, and Review of Plans for Use and Development of Water and Related Land Resources." Senate Document No. 97, 87th Congress, 2nd Session, May 29, 1962.

Ramsey, F. P., "Truth and Probability," Studies of Subjective Probability. H. E. Kyburg and. H. E. Smokler, eds., Wi Tey \& Sons, NY, pp. 61-92, 1964.

Randa11, A. 0., et a1., "Estimating Environmental Damages from Surface Mining of Coal in Appalachia: A Case Study," 1974. U.S. Envirronmental Protection Agency, 1977.

Randa11, A., "Evaluating Non-Market Goods and Services: Some Conceptual Considerations." Staff Paper 51, Dept. of Ag. Economics, University of Kentucky, Lexington, KY, 1977.

Rowe, W. D., An Anatomy of Risk, Wiley \& Sons, Inc., New York, 1977

Samuelson, P. A., "Principles of Efficiency, Discussion." American Economic Review, May 1964 .

Sandmo, Agnar and Jacques H. Dreze, "Discount Rates for Public Investment in Closed and Open Economies." Economica, 395-412, Nov. 1971.

Schelling, T. C., "The Life You Save May Be Your Own," Problems in Public Expenditure Analysis. S. B. Chase, ed., The Brookings Institution, Washington, D.C., 7968.

Schulze, William D., "Remarks for the Session of Bidding Games and Asking Approach," EPRI: Proceedings of a Workshop on the Measure of Intangible Environmental Impacts. Special Report, March 1977.

Sinden, J. A., "Utility Analysis in the Valuation of Extra-Market Benefits With Particular Reference to Water-Based Recreation." Water Resources Research Institute, Oregon State University, Corvali is, OR, WRRI-17, March 1973.

Sinden, J. A., "A Utility Approach to the Valuation of Recreational and Aesthetic Experiences." Amer. J.Agr. Econ., 56 (1):Feb. 1974.

Sjaastad, Larry. A. and Daniel L. Wisecarver, "The Social Cost of Public Finance." J. Pol. Econ. 5-13-547, June 1977.

Stevens, S. S., "Measurement, Psychophysics, and Utility," in C. W. Churchman and P. Ratoosh, editors, Measurement: Definitions and Theories, John Wiley and Sons, NY, 1959.

Tullock, Gordon, "The Social Rate of Discount and the Optimal Rate of Investment: Comment." Qty. J. Econ., pp. 337-336, May 1964. 


\section{DISTRIBUTION}

No. of

Copies

OFFSITE.

D. S: Ballantine

DOE Division of Biomedical and Environmental Research Washington, DC 20545

N. F. Barr

DOE Office of Technology

Impacts

Washington, DC 20545

W. G. Belter

DOE Office of Technology Impacts

Washington, DC 20545

R. 'P. Blaunstein

DOE Office of Technology Impacts

Washington, DC 20545

W. W. Burr

DOE Division of Biomedical and Environmental Research Washington, DC 20545

E. S. Burton

DOE Resource Applications and Evaluation

Nashington, OC 20545

R. L. Butenhoff

DOE Division of Biomedical and Environmental Research Washington, DC 20545

C. E. Carter

DOE Division of Biomedical and Environmental Research Washington, DC 20545

Paul Cho

DOE Office of Technology

Impacts

Washington, DC 20545
No. of

Copies

A. A. Churm

DOE Chicago Patent Group

9800 South Cass Avenue

Argonne, IL 60439

J. A. Coleman

DOE Office of Technology Impacts

Washington, DC 20545

R. D. Cooper

DOE Office of Technology Impacts

Wasinington, DC 20545

C. W. Edington

DOE Division of Biomedica? and Environmental Research Washington, DC 20545

W. O. Forster

DOE Division of Biomedica] and Environmental Resesrch Washington, DC 20545

P. H. Gerhardt

DOE Office of Technology Impacts

Washington, DC 20545

A. J. Goldberg

DOE Office of Technology Impacts

Washington, DC 20545

E. E. Held

NRC Office of Standards Development Washington, DC 20555

H. L. Hollister

DOE Operational and Environmentai Safety

Washington, DC 20545 
No. of

Copies

P. W. House

DOE Office of Technology Impacts

Washington, DC 20545

A. B. Joseph

DOE Office of Nuclear

Regulatory Research

Washington, DC 20555

J. L. Liverman

DOE Assistant (acting) Secretary for Environment

Washington; DC 20545

F. G. Lowman

DOE Office of Nuclear

Regulatory Research

Washington, DC 20555

D. M. Monti

DOE Office of Technology

Impacts

Washington, DC 20545

W. E. Mott

DOE Division of Environmental

Controi Technology

Washington, DC 20545

$R$. R. Newton

DOE Office of Technology Impacts

Washington, DC 20545

M. Reility

DOE Division of Fossil Energy

Washington, DC 20545

G. J. Rotariu

DOE Office of Technology

Impacts

Washington, DC 20545

R. D. Shull

DOE Office of Technology

Impacts

Washington, DC 20545
No. of

Copies

\section{H. Slade}

DOE Division of Biomedical and Environmental Research Washington, DC 20545

J. Swinebroad

DOE Division of Biomedical and Environmental Research Washington, DC 20545

B. W. Wachholz

DOE Office of Technology Impacts

Washington, DC 20545

H. R. Wasson

DOE Office of Technology Impacts

Washington, DC 20545

W. H. Weyzen

DOE Division of Biomedical and Environmental Research Washington, DC 20545

E. R. Williams

DOE Office of Technology Impacts.

Washington, DC 20545

R. W. Wood

DOE Division of Biomedical and Environmental Research Washington, OC 20545

27 DOE Technical Information Center

E. Croke

Argonne National Laboratory 9700 South Cass Avenue Argonne, IL 60439

L. J. Hoover Argonne National Laboratory 9700 South Cass Avenue Argonne, IL 60439 
No. of

Copies

P. M. Meier

Building 475

Brookhaven National Laboratory Upton; NY 11973

P. Palmedo

Building 475

Brookhaven National Laboratory Upton, NY 11973

W. E. Siri

University of California

Lawrence Berkeley Laboratory

Berkeley, CA 94720

D. Layton

University of California

Lawrence Livermore Laboratory

P.0. 30x 808

Liverfiore, CA 94550

A. Ford

Los Alamos Scientific

Laboratory

P. 0. Box 1663

Los Alamos, NM- 87545

E. Hammel

Los Alamos Scientific Laboratory

P.0. Box 1663

Los Alamos, NM 87545

R. K. Lohrding

Los Alamos Scientific Laboratory

University of California

P.0. Box 1663

Los Aiamos, NM 87545

R. M. Davis

Oak Ridge National Laboratory

P.0. Box X

Oak Ridge, TN 37830

W. Fulkerson

Oak Ridge National

Laboratory

P.0. Box $X$

Oak Ridge, TN 37830
No. of

Copies

ALASKA

J. Halterman

State Clearinghouse

Division of Policy Development and Planning

Office of the Governor

Pouch AD

Juneau, AK 99801

J. Lowel1 Jensen

Public Utilities Commission

Mackay Building

338 Denali Street

Anchorage, AK 99501

G. Martin

Department of Natura? Resources

State Office Building

Pouch $M$

Juneau, AK 99811

C. Quinian

Department of Commerce and Ecoriomic Development

Mackay Building

338 Denali Street

Anchorage, AK 99501

Col. G. R. Robertson

District Engineer

Alaska District

Corps of Engineers

P.0. Box 7002

Anchorage, AK 99510

\section{CALIFORNIA}

S. Boris

Teknekron Corporation

2118 Milvia Street

Berkeley; CA 94704 
No. of

Copies

T. E. Browne

Electric Power Research Institute

P.0. Box 10412

Palo Alto, CA 94304

R. Crow

Electric Power Research Institute

P.0. Box 10412

Palo Alto, CA 94304

R. Doe 11

U.S. Geological Survey

354 Middlefield Road

Menlo Park, CA 94025

M. Greenburger

Electric Power Research Institute

P.0. Box 10412

Palo Alto, CA 94304

L. Henning

Electric Power Research Institute

P.0. Box 10412

Palo Alto, CA 94304

iH. A. Kornberg

Electric Power Research Institute

P.0. Box 10412

Palo Alto; CA 94304

D. N. Morris

The Rand Corporation

1700 Main Street

Santa Monica, CA 90406

E. Neblet

DOE Federal Energy Regulatory Commission

U.S. Custom House

San Francisco, CA 94111

M. Searle

Electric Power Research Inistitute

P.0. Box 10412

Palo Alto, CA 94304
No. of

Copies

IDAHO

R. E. Wyzga

Electric Power Research Institute

P. 0. Box 10412

Palo Alto, CA 94304

R. H. Bendio

Idaho Power Company

P.0. Box 70

Boise, ID 83721

D. Guss

Bureau of State Planning and Community Affairs

State House

Boise, ID 83720

L. K. Hall

Idaho Energy Office

State House

Boise, ID 83720

J. McFadden

Energy, Inc.

Box 736

Idaho Falls, ID 83401

M. Nevitie

Idaho Legislative Council

State House

Boise, ID 83702

K. D. Smith

Public Utilities Commission

472 W. Washington Street

Boise, ID 83720

R. J. Vissia

Bureau of Reclammation

Federal Building

550 west Fort Street

Boise, ID 83724

R. N. Wise

Bureau of State Planning and Community Affairs

State Housa

Boise, ID 83720 
No. of

Copies

$\underline{\text { ILLINOIS }}$

J. P. Hartnett

Energy Resources Center

University of Illinois

at Chicago Circle

P. O. Box 4348

Cnicago, IL 60680

\section{MONTANA}

\section{3: Binanado}

Bureau of Land Management

P.0. Box 30157

Billings, MT 59107

K. Blackburn

01d West Regional Commission

Fratt Building, Suite $306 \mathrm{~A}$

Billings, MT .59101

R. A. Hofacker

Montana Power Company

40 East Broadway

Butte, MT 59701

R. Hulme

State Clearinghouse

Office of Budget and

Program Planning

232 Capitol Building

Helena, MT 59601

M. 0. Mortensen

Energy Advisory Counci1

c/o Lt. Governor's Office

Capitol Building

Helena, MT 59601

K. Muller

Northern Plains Resource

Council

418 Stapleton Building

Billings, MT 59101

J. Nybo

Energy Advisory Council

c/O Lt. Governor's Office

Capitol Building

Helena, MT 59601
No. of

Copies

W. Opitz

Public Service Commission

122711 th Avenue

Helena, MT 59601

B. Roberts

State Land Use

Planning Bureau

Department of Community Affairs

Capitol Post office

Helena, MT 59601

W. Tomlinson

Environmental Library

Room 208A, Natural Sciences

University of Montana

Missoula, MT 59801

A. C. Tsao

Energy Planning Division

Department of Natural Resources and Conservation

32 South Ewing

Helena, MT 59601

$\underline{\mathrm{OHIO}}$

Ann Rudolon

Battelle Memorial. Institute

505 King Avenue

Columbus, $\mathrm{OH} 43201$

\section{OREGON}

Col. H. L. Arnold, Jr.

District Engineer

Portland District

Corps of Engineers

P.O. Box 2946

Portland, OR 97208

H. Brauner

Conservation and Development Commission

1175 Court Street, N.E.

Salem, OR 97301 
ivo. of

Copies

Charles Davis

Public Utility Commissioner Labor and Industries Building Salem, OR 97310

R. A. Duncan

Northwest Power Pool

920 S. W. Sixth Avenue Room 1210

Portiand, OR 97204

L. Harris

Western Aluminum Producers Association

P.0. Box 8484

Portland, OR 97207

J. Hoozen

Bonneville Power Administration P.0. Box 3621

Portland, OR 97208

J. Jaksch

Corvallis Environmental

Research Laboratory

U.S. Environmental

Protection Agency

Corvallis, OR 973331

M. Katz

Bonneville Power Administration

P. 0. Box 3621

Portland, OR 97208

J. E. Kiley

Bonneville Power Administration

P.0. Box 3621

Portland, OR 97208

D. J. Lewis

Pacific Northwest Utilities Conference Committee

920 S.W. Sixth Avenue

Portland, UR $9 / 204$

J. C. Loosit

Bonnevile Power Administration

P.0. Box 3621

Portland, OR 97208
iNo. of

Copies

F. D. Miller

Oregon Department of Energy

528 Cottage, N.E.

Salem, OR 97310

R. T. Miller

Northwest Natural Gas Company

123 N.W. Flanders Street

Portland, OR 97209

0. Osborne

Oregon State University

Electrical Engineering

Department

Corvallis, OR 97331

Maj. Gen. W. E. Peel

Division Engineer

North Pacific Division

Corps of Engineers

210 Custom House

Portiand, OR 97209

G. A. Perrault

Portland General Electric Company

621 S.W. Alder Street

Fortland, OR 97205

R. E. Peterson

Pacific Power and Light

Public Service Building

Portland, OR 97204

C. L. Sauvie

Portland General Electric Company

621 S.W. Alder Street

Portland, OR 97205

J. T. Stiles

Pacific Power and Light

Public Service Building

Portland, OR 97204

i. H. Watkins

Bonneville Power Administration P. 0. Box 3621

Portland, OR 97208 
No. of

Copies

J. L. Willi iams

Portland General Electric Company

621 S.W. Alder Street

Portland, OR 97205

J. W. Wolfe

Oregon State University

Agricultural Engineering

Department

Corvallis, OR 97331

W. K. Woods

Energy Facility Siting Division

Department of. Energy

528 Cottage, N.E.

Salem, OR 97310

W. Young

Intergovernmental Relations

Division

Office of the Governor

240 Cottage Street, S.E.

Salem, OR 97310

$\underline{U T A H}$

J. A. Barnett

Western States Water Council

220 South Second East,

Suite 200

Salt Lake City, UT 84111

WASHINGTON

F. S. Adair

Washington State Department

of Commerce and Economic

Development

01.ympia, WA 98504

Col. C. J. Alkaire

Distric Engineer

Walla Walla District

Corps of Engineers

Building 602, City-County

Airport

Walla Walla, WA 99362
No. of

Copies

L. Bradley

Washington State Energy Office

1000 Cherry

OTympia, WA 98504

J. Brar

Washington State University

Pullman, WA 99163

W. E. Bruner

Pacific Northwest Regional Commission

1205 Washington

Vancouver, WA 98660

F. Claggett

Office of Community Development

State of Washington

400 Capitol Center Building

Vancouver, WA 98660

L. E. Coate

U.S. Environmental Protection Agency

1200 Sixth Avenue

Seattle, WA 98101

G. Culp

Culp, Dwyer, Guterson, and Grader

Hoge Building

Second and Cherry

Seattle, WA 98104

H. G. Curtis

Public Power Council

P.0. Box 1307

Vancouver, WA 98660

J. W. Ellis

Puget Sound Power and Light Company

Puget Power Building

Bellevue, WA 98009 
No. of

Copies

H. C. Elmore

Pacific Northwest Utilities Conference Committee

P.O. Box 1231

Wenatchee, WA 98801

L. E. Hal1

Puget Sound Power and Light Company

Puget Power Building

Bellevue, WA 98009

H. W. Harding

washington Water Power Company

P.0. Box 3727

Spokane, WA 99220

G. Hinman

Washington State University

Pulliman, WA 99163

H. Kosmata

Washington Public Power

Supply System

3000 George Washington Way

Richland, WA 99352

J. W. LaFond

City of Seattle

Department of Lighting

1015 Third Avenue

Seattie, WA 98104

D. J. Lane

Pacific Northwest River Basins Commission

1 Columbia River

P.O. Box 980

Vancouver, WA 98660

N. Lewis

Office of Program Planning and Fiscal Management

State Planning Division

House Office Building

Olympia, WA 98504
No. of

Copies

B. Pearson

RIS Library

Department of Ecology

Olympia, WA 98504

R. Polzin

Energy Facility Site

Evaluation Council

820 East Fifth Avenue

O1ympia, WA 98504

Col. J. A. Poteat, Jr.

District Engineer

Seattle District

Corps of Engineers

1579 Alaskan Way South

Seattle, WA 98134

D. Renberger/G. F. Bailey

Washington Public Power

Supply System

3000 George Washington Way

Richland, WA 99352

J. B. Robertson

DOE, Room 1992

Federal Building

915 Second Avenue

Seattle, WA 98174

P. H. Rose

Mathematical Sciences Northwest, Inc.

P.0. Box .1887

Bellevue, WA 98009

E. T. Shaw

Utilities and Transportation Commission

Highways-Licenses Building

Olympia, WA 98504

R. G. Sheehan City of Seattle

Department of Lighting

1015 Third Avenue

Seatile, WA 98104 
No. of

Copies

R. Tillson

Washington Public Power

Supply System

3000 George Washington Way

Richland, WA 99352

B. C. Thomas

Puget Sound Power and Light Company

Puget Power Building

Bellevue, WA 98009

M. Walsh

Department of Ecology

State of Washington

Olympia, WA 98504

W. C. Wolkenhauer

Washington Public Power

Supply System

3000 George Washington Way

Richland, WA 99352

R. Woodruff

Washington Public Fower

Supply Sysiem

3000 George Washington Way

Richland, WA 99352

\section{WYOMING}

A. J. Eliopulos

Public Service Commission

Supreme Court Building

Chyenne, WY 82002

D. B. Freudenthal

State Planning Coordinator's Office

Office of the Governor

State Capitol

Cheyenne, WY 82002

D. Hoffman

Mineral Development Division

Department of Economic Planning and Development

720 west 18th Street

Cheyenne, WY 82002
No. of

Copies

ONSITE

3 DOE Richland Operations Office

P. W. Gotischalk

W. Lei

H. E. Ransom

95 Pacific Northwest Laboratory

R. C. Adams

W. J.'Bair

C. H. Bloomster.

D. L. Brenchley

J. B. Brown

S. M. Brown

J. B. Burnham

N. E. Carter

D. B. Cearlock

M. Clement

J. W. Currie (5)

A. E. Davis

D. E. Deonigi

D. W. Dragnich

D. L. Elliott

L. E. Erickson (10)

D. W. Fraley

T. J. Foley

J. C. Fox

C. A. Geffen

P. L. Hendrickson

D. L. Hessel

W. T. Hinds

R. L. Hooper

J. J. Jacobsen

J. C. King

J. W. Ljtchfield (5)

S. Marks

C. L. McDonald (5)

A. R. Olsen

E. L. Owzarski

D. S. Renne

W. H. Rickard

W. F. Sandusky

L. C. Schmid

W. H. Swift

W. L. Templeton 
ONSITE

B. E. Vaughan

M. L. Warner

R. D. Widrig

G. L. Wilfert

T. L. Willke

W. K. Winegardner

Economics Library (20).

Technical Information

Files (5)

Technical Publications (2)

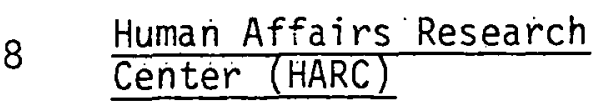

M. Green

J. A. Hébert

S. M. Nealey

S. Malhotra

M. Mertaugh

D. J. Merwin

M. E. OTsen

R. E. Schuller 